Article

\title{
Development of Body-Tissue Temperature-Control Transducer
}

\author{
Audrone Dumciene ${ }^{1, *}$ (i) and Saule Sipaviciene ${ }^{2}$ \\ 1 Department of Health, Physical and Social Education, Lithuanian Sports University, Sporto St. 6, \\ LT-44221 Kaunas, Lithuania \\ 2 Department of Applied Biology and Rehabilitation, Lithuanian Sports University, Sporto St. 6, \\ LT-44221 Kaunas, Lithuania; saule.sipaviciene@1su.lt \\ * Correspondence: audrone.dumciene@lsu.lt; Tel.: +370-698-277-66
}

Received: 9 November 2018; Accepted: 17 December 2018; Published: 20 December 2018

\begin{abstract}
The aim of this study was to develop a transducer for non-invasive temperature measurement in deeper tissue layers during tissue cooling. Simulation of the temperature field distribution in human tissues and the transducer were done, and the influence of transducer structure and material properties were studied. Using simulation results, the experimental transducer was designed for temperature measurement in deeper tissue layers during cooling. The temperature measurements with the needle thermometer and the transducer were well correlated at both before tissue cooling $r=0.723$ and after cooling $r=0.945$, and the temperature difference was no more than $\pm 0.2^{\circ} \mathrm{C}$.
\end{abstract}

Keywords: body temperature; sensors; transducer

\section{Introduction}

Several concepts are used in human-body temperature measurements-core body temperature, body temperature, muscle temperature, body skin temperature, etc.

The functioning of body-temperature measuring devices is based on various physics principles (nonelectric, thermoelectric, resistance, impedance, semiconductors, fiberoptic, ultrasonic, etc.). There is no rigorous classification of body-temperature measurement methods and gear due to the invasiveness. Gear can be divided into invasive, if an invasion in the human body is necessary to over-extend the skin; less-invasive, if natural body openings are used for temperature measurement; and non-invasive, if body temperature is measured on intact skin surface [1,2].

Core-body temperature can be most accurately measured with a gear known as the Swan-Ganz catheter, which is invasively introduced into the pulmonary artery, or by an esophageal catheter inserted into the esophagus [3]. The core-body temperature of healthy people is in the range of $37^{\circ} \mathrm{C} \pm 0.6{ }^{\circ} \mathrm{C}$, which can be changed with the circadian rhythm. This temperature is assumed to be relatively standard, and it is called the "gold standard." Invasive temperature measurements in deeper layers of tissue are performed using needle thermometers (thermocouple) [4-6].

For precise less-invasive body-temperature measurements, tympanic ear, oral, and rectal thermometers are more commonly used [7-9]. Some studies have shown that the normal body temperature, measured by less-invasive body-temperature methods, can be in the range of $36.2^{\circ} \mathrm{C}$ to $37.5^{\circ} \mathrm{C}[10]$.

The advantages and disadvantages of invasive and less-invasive methods have been discussed [1], stating that invasive (pulmonary artery, esophagus, and nasopharynx) methods are only clinically relevant and associated with certain risks, while less-invasive (urinary bladder and rectum) methods are less accurate [1]. 
In the absence of a commonly agreed classification of body-temperature measurement methods, some researchers assign methods and gears to non-invasive if the natural body openings are used for temperature measurement [11-16].

Non-invasive measurements of human body temperature utilize various digital medical thermometers, in which thermistors are commonly used as temperature sensors. Known as "zero-heat-flow" (ZHF) temperature gauges, they come with the following options-a heat source to create a heat-flow equilibrium between the human body and an artificial heat source $[3,17,18]$, two sensors that do not require a heat source [19-21], and four temperature transducers [22], which have been used in various studies [23]. Magnetic Resonance Imaging (MRI) [24] and the multi-frequency impedance method [25] are used to monitor the distribution of temperature fields in tissue.

The most common tools used for measuring skin temperature are contactless infrared and conductive devices $[26,27]$. There are commercial non-invasive body temperature ZHF sensors, with a declared accuracy of $25^{\circ} \mathrm{C}$ to $43^{\circ} \mathrm{C} \pm 0.2{ }^{\circ} \mathrm{C}$ [28].

A comprehensive comparative study of invasive (a urinary bladder temperature probe), semi-invasive (in the esophagus during vascular surgery and in the nasopharynx and the pulmonary artery during cardiac surgery), and non-invasive measurements of temperature using zero-heat-flux sensor type SpotOn skin probe on the forehead and skin temperature probe on the forehead was conducted [1]. The results of this study showed a good agreement (95\% limit of agreement) between zero-heat-flux sensor body measurements and invasive measurements. But there was a bad coincidence when the body temperature was below $32^{\circ} \mathrm{C}$. The forehead skin temperature was " 2 to $30^{\circ} \mathrm{C}$ lower than the deep body temperature" [1] (p. 976). Thus, according to Reference [1], the SpotOn skin probe is suitable for body temperature and core temperature measurements alongside invasive methods until the body temperature is higher than $32^{\circ} \mathrm{C}$.

Body-temperature measurements by non-invasive methods, the author's so-called skin-temperature measurement methods, are extensively analyzed in a review article [29]. It states that, in their opinion, there is no universally acceptable method of measurement to measure the temperature of the skin. The measurement results can be influenced by many factors such as sensor properties, clamping, and attaching to a particular body, environmental conditions, and other factors. It is likely that the thermal balance between the body's area covered with a sensor and its environment results in heat-transfer conditions different from that in the adjacent uncovered skin zones, and the measured temperature should usually differ from the temperature of the adjacent areas of the skin.

For measuring temperature in deeper tissue layers, needle thermometers are usually used, which are inserted $2-4 \mathrm{~cm}$ in depth [6,30-37]. They must be sterilized before use and disinfected after use. This measurement procedure is not pleasant to the subject.

The above-discussed methods and gears were used to measure body, body core, and skin temperature, but we did not find any research that proves that these methods and gears could be used to determine the temperature at a certain tissue level. This is required for the research on the effects of cooling on muscle properties [31,32], or of cooling for treatment [4,6,32-37].

The temperature in deeper tissue layers was measured by microwave radiometry in which the tissues were heated by high-intensity-focused ultrasound, and using temperature imaging algorithm, the temperature distribution was calculated in real time [38], and microwave radiometry was used for the brain temperature measurement [39]. The mathematical model that describes the relationships of the core temperature with the individual physical activity, heart rate, skin temperature, ambient temperature, and relative humidity was proposed in a previous study [40]. An algorithm was developed for calculating the core temperature from the measurements data mentioned above. In Reference [41], a model to calculate core body temperature from heart rate observation data was proposed, but it needed continuous heart rate monitoring. Mathematical models [42] enabling assessment of core-body temperature using individual characteristics, physical activity, clothing biophysics, and environmental conditions were created. A model was proposed in study [43] for core-body temperature prediction using the skin temperature over the carotid artery measurement 
data. New design for non-invasive core temperature measurement using ZHF method was proposed and used in Reference [44]. Intramuscular temperature can be predicted at a depth of $2 \mathrm{~cm}$ using the equation proposed in Reference [33], which includes variables like time, skin temperature, skinfold, room temperature, and body core temperature. Temperature was measured at the given tissue depth using diffuse optical spectroscopic imaging method and a relevant equipment [45]. A method of temperature estimation that was based on the thermal dependence of the acoustic speed in a heated medium was used in Reference [46]. Novel photoacoustics sensor was proposed and used in study [47] for non-invasive monitoring of blood temperature.

The methods implemented in References [38,45,46] hold a possibility for temperature measurement in tissue deeper layers and in local areas unlike the methods used in References [40-44,47] for measuring core body temperature, but the equipment based on the diffuse optical spectroscopic imaging method or the thermal dependence of the acoustic speed in a heated medium is complicated to use in additional cases, for example, when treating with an ice pack after injury or trauma.

It was shown in Reference [31] that skin surface temperature during cooling versus time change almost linearly. It was found in Reference [6] that when the surface (skin) temperature varied linearly in time during cooling, temperature of muscles at $2 \mathrm{~cm}$ depth also varied linearly with time. So, if it was possible to measure the temperature of the tissue surface area, thermo-isolated from the thermal effects of the environment, then the tissue temperature at a depth of $3 \mathrm{~cm}$ can be calculated using the following equation [48]:

$$
T=0.5026 \times T_{\text {ss }}+18.399
$$

where $T_{\mathrm{ss}}$-temperature on the skin surface measured by the transducer.

Therefore, the purpose of this study was to find out the possibility and develop an instrument for measuring temperature in deeper layers of tissue, without the use of needle thermometers, but by measuring temperature on intact skin surface during cooling.

\section{Materials and Methods}

Here, we discuss a new multisensory transducer design, of which the structure is shown in Figure 1. This is because the thermal channel and isolation cover dimension and the influence of the channel material have not been clarified.

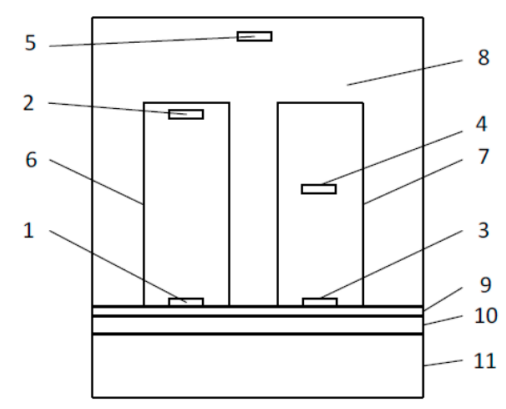

Figure 1. Transducer structure: 1, 2, 3, 4, and 5-temperature sensors (Thermistor 5 can be used to inspect the thermo-isolation cover); 6 -thermal channel; 7-thermal channel; 8-thermo-insulation cover; 9-skin; 10—fat; and 11-muscle.

The thermal equivalent circuit of the transducer shown in Figure 1 without considering the influence of the thermistors can be formed, as shown in Figure 2. 


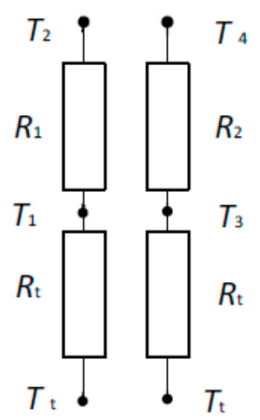

Figure 2. Equivalent resistance circuit of two heat-flow channels. $T_{\mathrm{t}}$ - deep tissue layer temperature; $T_{1}$-sensor 1 temperature; $T_{2}$-sensor 2 temperature; $T_{3}$-sensor 3 temperature; $T_{4}$-sensor 4 temperature; $R_{\mathrm{t}}$-tissue thermal resistance; $R_{1}$-thermal resistance of one thermal channel; and $R_{2}$-thermal resistance of another thermal channel.

The temperature on the boundary between the skin surface and the transducer pad can be calculated using the following modified equation [48]:

$$
T_{t}=\frac{T_{1} \cdot \lambda\left(T_{3}-T_{4}\right)-T_{3}\left(T_{1}-T_{2}\right)}{\lambda\left(T_{3}-T_{4}\right)-\left(T_{1}-T_{2}\right)}
$$

where $T_{1}, T_{2}, T_{3}$, and $T_{4}$-temperatures at points shown in Figure 2; and $\lambda$-ratio of thermal channel thermal resistance $R_{1} / R_{2}$.

This ratio $\lambda$ must be higher than four [48]. So, the ratio of thermal resistors $R_{1}$ and $R_{2}$ of the thermal channels in this study was equal to five.

To determine the optimum parameters of the transducer, a simulation of the distribution of temperature fields in the human tissue and the transducer structure was performed.

The human body, using nutrients, generates bioheat. Due to the flow of blood and the heat-transfer process, heat is transferred to the entire body until it is balanced with the environment. The description of heat propagation in living organisms is most often done with the Pennes' [49] equation or its modifications, which assess specific conditions [50-52]. Using the Pennes' equation and the boundary conditions established for the variants under consideration, one can simulate the heat-propagation process in the human body and calculate the distribution of temperature fields.

Thus, the bioheat-transfer process in the human body can be described by the following equation [49]:

$$
\delta_{t s} \rho C \frac{\delta T}{\delta t}+\nabla \cdot(-k \nabla T)=\rho_{b} C_{b} \omega_{b}\left(T_{b}-T\right)+Q_{m}+Q_{e x}
$$

where $\delta_{t s}$-a time-scaling coefficient (dimensionless); $\rho$-tissue density $\left(\mathrm{kg} / \mathrm{m}^{3}\right) ; C$-specific heat of tissue $(\mathrm{J} /(\mathrm{kg} \cdot \mathrm{K})) ; k$ - tissue's thermal conductivity tensor $(\mathrm{W} /(\mathrm{m} \cdot \mathrm{K})) ; \rho_{b}$-blood density $\left(\mathrm{kg} / \mathrm{m}^{3}\right)$; $C_{b}$-specific heat temperature $(\mathrm{K}) ; Q_{m}$-heat source from metabolism $\left(\mathrm{W} / \mathrm{m}^{3}\right) ; Q_{e x}$-spatial heat sourse in body of blood $\left(\mathrm{W} / \mathrm{m}^{3}\right) ; \omega_{b}$-blood-perfusion rate $\left(\mathrm{m}^{3} /\left(\mathrm{m}^{3} \cdot \mathrm{s}\right)\right) ; T_{\mathrm{b}}$-arterial blood temperature $(\mathrm{K})$; $T$-dependence variable temperature $(\mathrm{K})$.

We investigated a case where the person is in a state of rest and at a relatively stable ambient temperature. In this case, we can write:

$$
\nabla \cdot(-k \nabla T)=\rho_{b} C_{b} \omega_{b}\left(T_{b}-T\right)+Q_{m}+Q_{e x} .
$$

If the person is in a state of rest, we can accept that $Q_{e x}=0$, and transform Equation (4) as

$$
\nabla \cdot(-k \nabla T)=\rho_{b} C_{b} \omega_{b}\left(T_{b}-T\right)+Q_{m} .
$$

Therefore, Equation (4) can be used to simulate temperature fields in the tissue. We are interested in the distribution of temperature fields in the tissue and in the transducer body. 
Since the volume of the transducer is small compared with the parts of the human body in which the temperature will be measured, the accuracy is reduced using Equation (5) for the propagation of heat in the transducer body.

Boundary conditions: $-\vec{n} \cdot(-k \nabla T)=q_{0}+h\left(T_{\text {ext }}-T\right)$-heat flux (external boundary of the tissue and the transducer model); $\vec{n} \cdot\left(k_{1} \nabla T_{1}-k_{2} \nabla T_{2}\right)=0$-continuity on the entire interior boundary between tissue layers and the transducer body model; $-\vec{n} \cdot(-k \nabla T)=0-$ using the symmetry of the object under study, the symmetry condition is given, where $T_{\text {ext }}$-external (bulk) temperature.

The human tissue model properties [53] used in the simulation are given in Table 1.

Table 1. Human tissue layer properties.

\begin{tabular}{cccccccc}
\hline Layer & $\boldsymbol{\rho}\left(\mathbf{k g} / \mathbf{m}^{\mathbf{3}}\right)$ & $\boldsymbol{k}\left(\mathbf{W} / \mathbf{m}^{*} \mathbf{K}\right)$ & $\boldsymbol{C} \boldsymbol{p}\left(\mathrm{J} / \mathbf{k g}^{*} \mathbf{K}\right)$ & Thickness $(\mathbf{m})$ & $Q_{m}\left(\mathbf{W} / \mathbf{m}^{\mathbf{3}}\right)$ & $\boldsymbol{\omega}_{\boldsymbol{b}} \mathbf{( 1 / s )}$ & $\boldsymbol{T}_{\boldsymbol{b}}(\mathbf{K})$ \\
\hline Muscle & 1090 & 0.5 & 3766 & 0.12 & 5 & 0.0001 \\
Fat & 850 & 0.16 & 2510 & 0.0025 & 0 & $4 / 5 \mathrm{E}-6$ \\
Skin & 1100 & 0.21 & 3250 & 0.002 & 4 & $7.2 \mathrm{E}-8$ \\
Blood & 1050 & 0.32 & 1313 & 0.03 & 310.15 \\
\hline
\end{tabular}

The COMSOL Multiphysics 3.5. software package was used to simulate temperature fields in the tissue and transducer body at an environment temperature of $20{ }^{\circ} \mathrm{C}$.

Precision Cantherm thermistor (Cantherm, Monteal, Canada), type MF51E103F3380, with a time constant of $\leq 3.2 \mathrm{~s}$ was used as temperature sensor that is intended for medical equipment. For the thermistor, a calibration procedure was conducted, and the Steinhart-Hart equation was used for the resistance temperature $R(T)$ characteristic approximation. The equation can be written as follows:

$$
1 / T=B_{0}+B_{1} \ln R_{T}+B_{3}\left(\ln R_{T}\right)^{3}
$$

where $T$-temperature in $\mathrm{K} ; B_{0}, B_{1}$, and $B_{3}$-equation coefficients; and $R_{T}$-thermistor resistance at the temperature $T$.

Coefficients $B_{0}, B_{1}$, and $B_{3}$ were estimated from thermistor calibration results, since the $R(T)$ characteristics from the manufacturer are not for individual thermistors, but averaged thermistor type MF51. The accuracy of calibrated thermistors after applying the linearization of the Steinhart-Hart equation was in the range of $\pm 0.02{ }^{\circ} \mathrm{C}$.

The structure of the physical model used for transducer examination is shown in Figure 3.

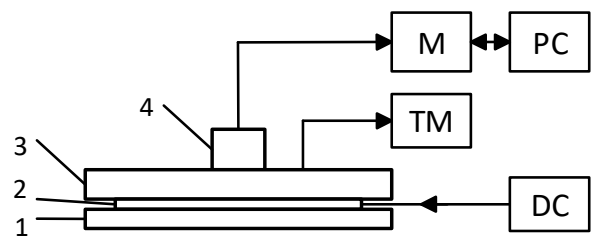

Figure 3. Structure diagram of the experiment. 1-cooler; 2-Peltier element; 3-polyethylene plate (phantom); 4-transducer; $\mathrm{M}$-temperature meter; $\mathrm{TM}$-temperature meter with thermo-probe; PC-laptop; and DC—programmable DC source.

Temperature was measured at six points using the FLUKE thermometer type Black Stack 1560 and Thermistor readout module type 2564 (readout four decimal digits after point). Reference temperature at the top of the polyethylene plate (phantom) was maintained within the range of $30 \pm 0.1^{\circ} \mathrm{C}$.

The temperature of transducer sensors 1, 2, 3, 4, and 5 was measured using, as noted above, a FLUKE thermometer.

The dimension of the thermal channel and the thermos-isolation cover is shown in Figure 4. 


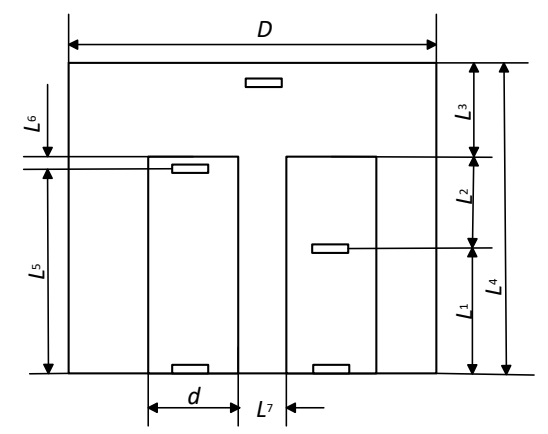

Figure 4. Main dimension of transducer elements.

Dimensions $\mathrm{L}_{1}, \mathrm{~L}_{2}, \mathrm{~L}_{3}, \mathrm{~L}_{4}, \mathrm{~L}_{5}, \mathrm{~L}_{6} \mathrm{~L}_{7}, \mathrm{D}$, and $\mathrm{d}$ shown in Figure 4 are used as variables by simulating the distribution of temperature fields in a transducer.

A hard-plastic cover and polyurethane foam for thermo-isolation and epoxy with cooper powder were used for the transducer design.

Ethical approval for an experiment with human subjects was granted by the Kaunas regional biomedical-research ethics committee, and measurements were taken in accordance with the Helsinki Declaration.

The experiment with the human subject included one volunteer. Before temperature measurements were taken, the test subject was lying supine on a laboratory bed for $15 \mathrm{~min}$ for relaxation in a room with a temperature of $20 \pm 1{ }^{\circ} \mathrm{C}$. The deep muscle temperature was measured using needle thermometer (Ellab A/S, type DM 852, Hillerød, Denmark). The skin of left thigh was prepared before each measurement by shaving and disinfecting before and after needle insertion with a pad saturated with isopropyl alcohol (Shanghai Channelmed Import \& Export Co., Ltd., Shanghai, China). Needle thermometer was inserted perpendicular to the skin covering of the muscle quadriceps femoris at a depth of $\sim 3 \mathrm{~cm}$ including one-half of the skinfold in the middle-third on the side of the femur. The skinfold was measured by the Holtain caliper (Siber Hegner GMP, Zurich, Switzerland). After measuring, the needle thermometer was extracted, and the skin was disinfected and sealed with a waterproof anti-bacterial patch on the spot.

Transducer was hermetically attached using adhesive tape $1 \mathrm{~cm}$ away from the needle thermometer and left during immersion in cold bath. The needle thermometer was sterilized after each use. The measurements were conducted before and repeated immediately after leg cooling. Test subject's leg was twice immersed for $15 \mathrm{~min}$ (with a $10 \mathrm{~min}$ break) in cold water bath $\left(15 \pm 1{ }^{\circ} \mathrm{C}\right)$ for cooling [54]. The measurement was repeated five times with two-week breaks. The patient was advised on the thermometer needle insertion site supervision and to inform researchers about any signs of infection.

\section{Results}

The distribution of the temperature fields in the tissue-transducer models (Figure 1), at different variables $\mathrm{L}_{1}, \mathrm{~L}_{2}, \mathrm{~L}_{3}, \mathrm{~L}_{4}, \mathrm{~L}_{5}$, and $\mathrm{L}_{6}$, when the environment temperature was $+20{ }^{\circ} \mathrm{C}$, is given in Figure 5 ( $a, b$, and c for different variable values). 


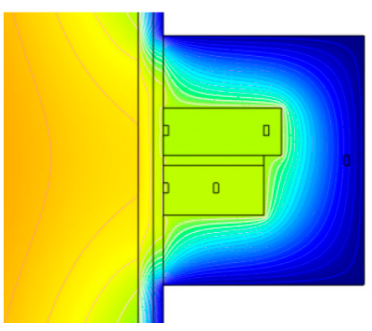

(a)

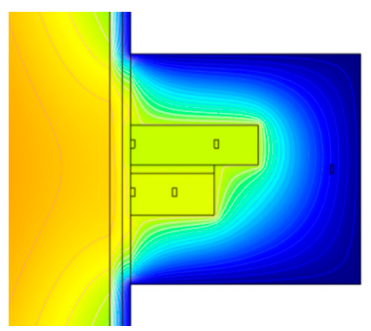

(b)

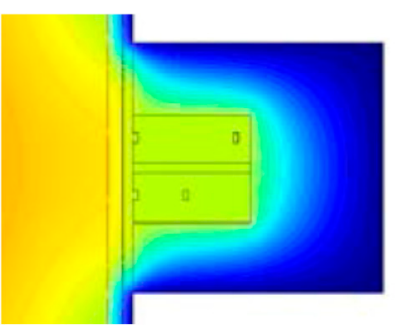

(c)

Figure 5. Distribution of temperature fields in the tissue and the transducer. (a) Transducer structure version when $\left(\mathrm{L}_{1}+\mathrm{L}_{2}\right)<\left(\mathrm{L}_{5}+\mathrm{L}_{6}\right)$; (b) Transducer structure version when $\left(\mathrm{L}_{1}+\mathrm{L}_{2}\right) \ll\left(\mathrm{L}_{5}+\mathrm{L}_{6}\right)$; (c) Transducer structure version when $\left(\mathrm{L}_{1}+\mathrm{L}_{2}\right)=\left(\mathrm{L}_{5}+\mathrm{L}_{6}\right)$ and $\mathrm{L}_{3}$ is higher than in versions $(\mathbf{a}, \mathbf{b})$. Variables $\mathrm{L}_{7}$ and $\mathrm{d}$ in all three versions are constant.

The simulation results of the influence of thermal channels materials' thermal conductivity in the temperature on the boundary between the tissue surface and the transducer pad are shown in Figure 6.

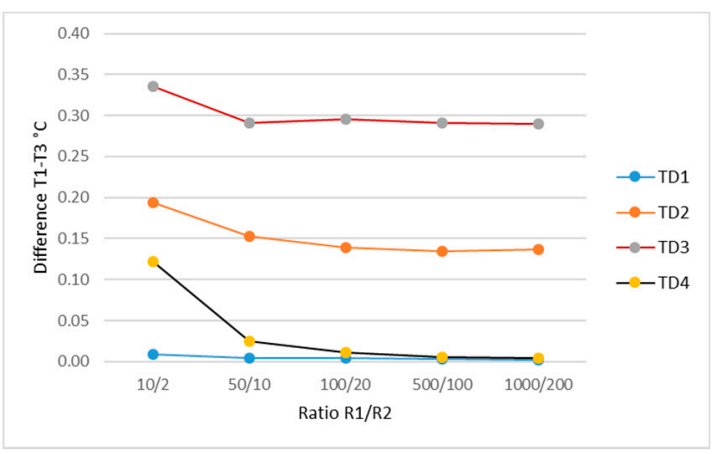

Figure 6. Influence of thermal channels materials' thermal conductivity on the material temperature at the boundary between the tissue surface and the transducer pad.

In the evaluation of simulation results, from Figure 6, it can be concluded that for the purpose of obtaining a lower transductor temperature time constant, the materials for a thermal channel are required to have a thermal conductivity of 500/100-1000/200 (where the thermal-conductivity coefficient of the short channel material is in a fraction denominator, and of the longer channel in a counter).

The optimization results of thermal-insulation cover thickness $\mathrm{L}_{3}$ (Figure 4 ) as a function of different temperatures $T_{1}$ and $T_{3}$ for illustration are shown in Figure 7.

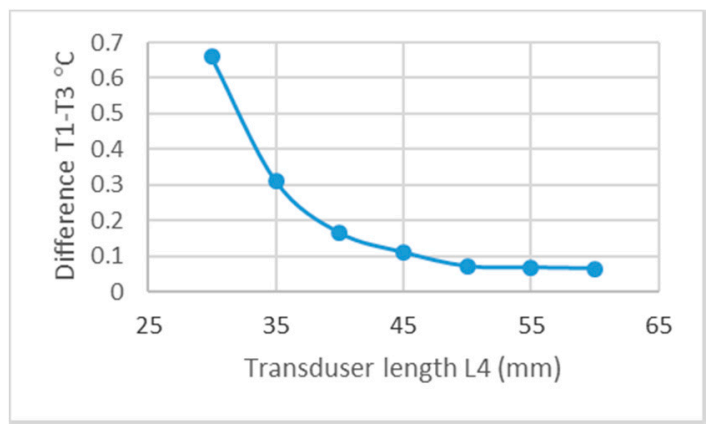

Figure 7. Influence of length $L_{4}$ on the $T_{1}-T_{2}$ difference.

The simulation results of the influence of the thermal-insulation cover thickness L6 (Figure 4) on the temperature on the boundary between the tissue surface and the transducer pad are shown in Figure 8 . 


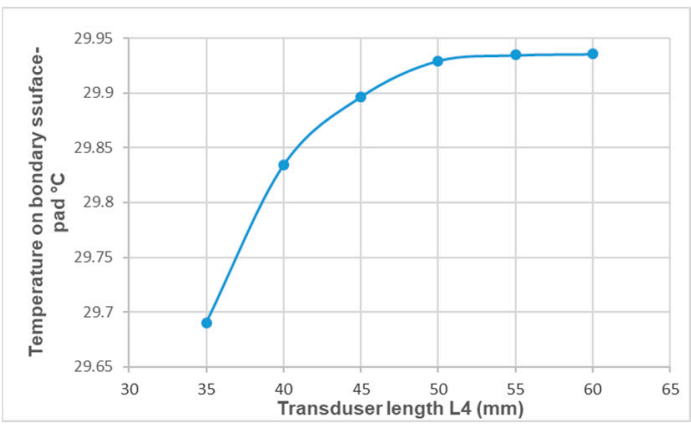

Figure 8. Influence of length $L_{4}$ on the temperature on the boundary between the tissue surface and the transducer pad.

The physical experiment with the transducer and phantom was repeated 10 times. The measured sensors' average temperatures were $T_{1}=30.367 \pm 0.0091{ }^{\circ} \mathrm{C}, T_{2}=30.161 \pm 0.0096{ }^{\circ} \mathrm{C}$, $T_{3}=30.199 \pm 0.0087{ }^{\circ} \mathrm{C}$, and $T_{4}=29.4521 \pm 0.0108{ }^{\circ} \mathrm{C}$. Temperature $T_{c p}$ on the boundary between the tissue surface and the transducer pad was calculated using Equation (2) and the values of the measured temperatures for $T_{1}, T_{2}, T_{3}$, and $T_{4}$. The estimated temperature $T_{\mathrm{sp}}$ of the experiment was $30.199 \pm 0.0494{ }^{\circ} \mathrm{C}$. The average temperature measured with the two thermistors located on the transducer can be calculated as $T_{\mathrm{a}}=\left(T_{1}+T_{3}\right) / 2$, and it was $T_{\mathrm{a}}=30.282{ }^{\circ} \mathrm{C}$. The difference is $T_{a}-T_{s p}=0.082{ }^{\circ} \mathrm{C}$. The predicted temperature at the depth of $3 \mathrm{~cm}$ in phantom was calculated by using Equation (1) and estimated temperature value $T_{\mathrm{cp}}$ was $33.58^{\circ} \mathrm{C}$.

The average deep-muscle temperature at a depth of $\sim 3 \mathrm{~cm}$ before cooling measured by needle thermometer was $36.62 \pm 0.147^{\circ} \mathrm{C}$ and after cooling was $32.48 \pm 0.117^{\circ} \mathrm{C}$; estimated by transducer before cooling was $36.489 \pm 0.262{ }^{\circ} \mathrm{C}$ and after cooling was $32.32 \pm 0.098^{\circ} \mathrm{C}$. The difference of average temperature values estimated by needle thermometer and transducer before cooling was $\pm 0.191{ }^{\circ} \mathrm{C}$ and after cooling was $\pm 0.168^{\circ} \mathrm{C}$. Correlation coefficient between temperature values measured with needle thermometer and using transducer before cooling was $r=0.723$ and after cooling was $r=0.945$.

\section{Discussion}

In the present study, we showed that temperature in the deeper tissue layers during cooling can be measured using transducer with two thermal channels and four precise thermistors. Results of simulation and physical experiment revealed the importance of thermal properties of thermal channels and thermo-isolation cover materials. The present research used the same steps to develop gear for the temperature measurement at a muscle depth of $3 \mathrm{~cm}$, and this is typical for researchers investigating changes in muscle endurance and responses and workload during muscle cooling, as well as controlling the effects of the treatment by cooling ice packets or other freezing agents.

In our opinion, it is complicated to use diffuse optical spectroscopic imaging method [45] or microwave scanning [39] equipment for temperature measurement during cooling in cold water bath or providing therapy with ice packs after trauma. In study [33], it was shown that when the skin temperature was measured with thermocouple without thermo-isolation enclosure, its value was a weak predictor of intramuscular temperature during cooling.

The transducer developed in our study actually measured the skin temperature (on border skin surface and transducer pad) and after calculation could predict the temperature in deeper layers of muscle. So, could other skin surface sensors be used to measure (predict) temperature in the deeper layers of the tissue during cooling?

For skin temperature measurement, various studies used thermocouples [6,33,37], infrared sensors [27,32], thermistors [29], with the number of types being 147 , as specified in a review article [30]. Other studies [29,55-57] showed that the measurement of the skin surface temperature with contact sensor was influenced by the ambient temperature, the sensor mounting method, and the method and quality of the thermal insulation of the sensor from the environment. 
In our studio, thermo-isolation cover parameters and selected materials with the most suitable thermal conductivity had been optimized in order to protect the developed transducer better against environmental influences. In addition, from the available literature, we did not find any information on the measurements of temperature in deeper tissue layers using skin sensor by cooling the tissue (human limbs) for comparison.

During this study, transducer thermistors' impedance was measured with a high-accuracy gauge Fluke-type Black Stack used in laboratory environments. For practical measurements in the transducer design, less precise, inexpensive ADC converters and a microprocessor can be used. However, it is likely to achieve less accuracy.

In a previous study [55], the temperature probe of the thermometer (accuracy $\pm 1{ }^{\circ} \mathrm{C}$ ) was inserted through the subcutaneous fat layer $1 \mathrm{~cm}$ into the muscle, and after cooling for $5 \mathrm{~min}$ with an ice pack, the temperature was $34.9 \pm 1.2{ }^{\circ} \mathrm{C}$. The inter-muscle temperature at a depth of $\sim 3 \mathrm{~cm}$ was measured in Reference [58], but they cooled the whole body at $14 \pm 1^{\circ} \mathrm{C}$ and the temperature decreased during cooling by $6.96 \pm 2.3^{\circ} \mathrm{C}$ after 170-min cooling time. Authors of Reference [34] inserted thermocouple at a depth of the skinfold thickness $+2 \mathrm{~cm}$ and used ice bags for cooling. In Reference [4], inter-muscle temperature was measured at a depth of $1 \mathrm{~cm}$ below the skin, and after $20 \mathrm{~min}$ of treatment with ice, the temperature decreased to $7^{\circ} \mathrm{C}$. In the study [32], subjects were exposed to $-110^{\circ} \mathrm{C}$ chamber for $4 \mathrm{~min}$ and $8{ }^{\circ} \mathrm{C}$ cold water immersion therapy. Correspondingly, the inter-muscle temperature decreased at $3 \mathrm{~cm}$ depth by $1.6 \pm 0.6^{\circ} \mathrm{C}$ and $1.7 \pm 0.5^{\circ} \mathrm{C}$. Various ice bag fixing methods were used during the cold treatment [6], and inter-muscle temperature was measured at a depth of $2 \mathrm{~cm}$ by thermocouple. The temperature drop in the 30-min time was, from initial value, from $5.6^{\circ} \mathrm{C}$ to $10.06{ }^{\circ} \mathrm{C}$ depending on the method of the ice bag fixing.

Based on the investigation results mentioned above, it can be stated that the temperature of the deeper muscle layers was measured, in most cases, in an invasive manner, but the results are difficult to compare with each other, because different types of cooling techniques and cooling temperatures were used, and the temperature was measured at various tissue depths.

In the future studies, the gear for temperature in deeper layers of the muscle during cooling measurement should be designed with transducer, software, microcomputer, and display. Studies should be conducted with a larger number of subjects and in both sexes (different skinfolds), and the measurement accuracy should be estimated.

\section{Conclusions}

Using simulation results, the experimental transducer was designed for the temperature measurement in deeper tissue layers during cooling. The temperature measurement with the needle thermometer and the transducer results were well correlated as before tissue cooling $r=0.723$ and after cooling $r=0.945$, and the temperature difference was no more than $\pm 0.2{ }^{\circ} \mathrm{C}$.

Currently, there are no commercially available sensors for measuring temperatures in deeper muscle layers during cooling human's limbs or for temperature control at a certain depth of tissue during treatment time with ice bags after trauma.

After commercialization, the developed transducer can be recommended for use in studies of muscles properties change during cooling and for temperature control in the treatment with ice bags after trauma.

Author Contributions: Conceptualization and methodology, A.D.; and conducting experiments, writing, review, and editing, S.S.

Acknowledgments: The authors would like to thank the colleagues from the Laboratory of measurement technology at Kaunas University of Technology for their assistance in conducting experiments.

Conflicts of Interest: The authors declare no conflicts of interest. 


\section{References}

1. Mäkinen, M.T.; Pesonen, A.; Jousela, I.; Päivärinta, J.; Poikajärvi, S.; Albäck, A.; Salminen, U.S.; Pesonen, E. Novel Zero-Heat-Flux Deep Body Temperature Measurement in Lower Extremity Vascular and Cardiac Surgery. J. Cardiothorac. Vasc. Anesthesia 2016, 30, 973-978. [CrossRef] [PubMed]

2. $3 \mathrm{M}^{\mathrm{TM}}$ Spot On ${ }^{\mathrm{TM}}$ Temperature Monitoring System. Available online: https://multimedia.3m.com/mws/ media/8781630/spoton-system-brochure.pdf (accessed on 9 October 2018).

3. Teunissen, L.P.J.; Klewer, J.; de Haan, A.; de Koning, J.J.; Daanen, A.M. Non-invasive continuous core temperature measurement by zero heat flux. Physiol. Meas. 2011, 32, 559-570. [CrossRef]

4. Myrer, J.W.; Measom, G.; Durrant, E.; Fellingham, G.W. Cold- and Hot-Pack Contrast Therapy: Subcutaneous and Intramuscular Temperature Change. J. Athletic Train. 1997, 32, 238-241.

5. Sargeant, A.J. Effect of muscle temperature on leg extension force and short-term power output in humans. Eur. J. Appl. Physiol. 1987, 56, 693-698. [CrossRef]

6. Tomchuk, D.; Rubley, M.D.; Holcomb, W.R.; Guadagnoli, M.; Tarno, J.M. The magnitude of tissue cooling during cryotherapy with varied types of compression. J. Athletic Train. 2010, 45, 230-237. [CrossRef] [PubMed]

7. Aadal, L.; Fog, L.; Pedersen, A.R. Tympanic ear thermometer assessment of body temperature among patients with cognitive disturbances. An acceptable and ethically desirable alternative? Scand. J. Caring Sci. 2016, 30, 766-773. [CrossRef]

8. Erdling, A.; Johansson, A. Core Temperature-The Intraoperative Difference Between Esophageal Versus Nasopharyngeal Temperatures and the Impact of Prewarming, Age, and Weight: A Randomized Clinical Trial. AANA J. 2015, 83, 99-105.

9. Yeoh, W.K.; Lee, J.K.W.; Lim, H.Y.; Gan, C.W.; Liang, W.; Tan, K.K. Re-visiting the tympanic membrane vicinity as core body temperature measurement site. PLoS ONE 2017, 12, e0174120. [CrossRef]

10. Flaifel, H.A.N.; Ayoub, F. Esophageal temperature monitoring. Middle East J. Anesth. 2007, 19, $123-147$.

11. Greenes, D.S.; Fleisher, G.R. Accuracy of a Noninvasive Temporal Artery Thermometer for use in Infants. Arch. Pediatr. Adolesc. Med. 2001, 155, 376-381. [CrossRef]

12. Farnell, S.; Maxwell, L.; Tan, S.; Rhodes, A.; Philips, B. Temperature measurement: Comparison of non-invasive methods used in adult critical care. J. Clin. Nurs. 2005, 14, 632-639. [CrossRef] [PubMed]

13. Hooper, V.D.; Andrews, J.O. Accuracy of noninvasive core temperature measurement in acutely ill adults: The state of the science. Biol. Res. Nurs. 2006, 8, 24-34. [CrossRef] [PubMed]

14. Lawson, L.; Bridges, E.J.; Ballou, I.; Greco, S.; Shively, J.; Sochulak, V. Accuracy and precision of noninvasive temperature measurement in adult intensive care patients. Am. J. Crt. Care 2007, 16, 485-496.

15. Bodkin, R.P.; Aquisto, N.M.; Zwart, J.M.; Toussaint, S.P. Differences in noninvasive thermometer measurements in the adult emergency department. Am. J. Emerg. Med. 2014, 32, 987-989. [CrossRef] [PubMed]

16. Fogt, D.L.; Henning, A.L.; Venable, A.S.; McFarlin, B.K. Non-invasive Measures of Core Temperature versus Ingestible Thermistor during Exercise in the Heat. Int. J. Exerc. Sci. 2017, 10, 225-233. [PubMed]

17. Fox, R.H.; Solman, A.J. A new technique for monitoring the deep body temperature in man from the intact skin surface. J. Physiol. 1971, 212, 8-10.

18. Steck, L.N.; Sparrow, E.M.; Abraham, J.P. Non-invasive measurement of the human core temperature. Int. J. Heat Mass Transfer 2011, 54, 975-982. [CrossRef]

19. Kimberger, O.; Thell, R.; Schuh, M.; Koch, J.; Sessler, D.I.; Kurz, A. Accuracy and precision of a novel non-invasive core thermometer. Br. J. Anaesthesia 2009, 9, 1-6. [CrossRef]

20. Gunga, H.C.; Werner, A.; Stahn, A.; Steinach, M.; Schlabs, T.; Koralewski, E.; Kunz, D.; Belavý, D.L.; Felsenberg, D.; Sattler, F.; Koch, J. The Double Sensor-A non-invasive device to continuously monitor core temperature in humans on earth and in space Respir. Physiol. Neurobiol. 2009, 169S, 63-68. [CrossRef]

21. Uth, M.F.; Koch, J.; Sattler, F. Body Core Temperature Sensing: Challenges and new Sensor Technologies. Procedia Eng. 2016, 168, 89-92. [CrossRef]

22. Kitamura, K.I.; Zhu, I.; Chen, W.; Nemoto, T. Development of a new method for the noninvasive measurement of deep body temperature without a heater. Med. Eng. Phys. 2010, 32, 1-6. [CrossRef] [PubMed] 
23. Guschlbauer, M.; Maul, A.C.; Yan, X.; Herff, H.; Annecke, T.; Sterner-Kock, A.; Böttiger, B.W.; Schroeder, D.C. Zero-Heat-Flux Thermometry for Non-Invasive Measurement of Core Body Temperature in Pigs. PLoS ONE 2016, 11, e0150759. [CrossRef] [PubMed]

24. Nakamura, S.; Nakamura, M.; Maeda, E.; Nikawa, Y. Study on Temperature Measurement Using MRI during Acupuncture and Moxibustion. Electron. Commun. Jpn. 2017, 100, 62-67. [CrossRef]

25. Komiya, H.; Maeda, J.; Suzuki, I. Development of multi-frequency impedance method of measuring muscle temperature noninvasively. Adv. Exerc. Sports Physiol. Date 2014, 15, 1-2.

26. Buono, M.J.; Jechort, A.; Marques, R.; Smith, C.; Welch, J. Comparison of infrared versus contact thermometry for measuring skin temperature during exercise in the heat. Physiol. Meas. 2007, 28, 855-859. [CrossRef] [PubMed]

27. Bach, A.J.E.; Stewart, I.B.; Disher, A.E.; Costello, J.T. A comparison between conductive and infrared devices for measuring mean skin temperature at rest, during exercise in the heat, and recovery. PLoS ONE 2015, 10, e0117907. [CrossRef] [PubMed]

28. $3 \mathrm{M}^{\mathrm{TM}}$ Bair Hugger ${ }^{\mathrm{TM}}$ Temperature Monitoring Patient Sensors, Model 36000. Available online: https:/ / www.3m.com/3M/en_US/company-us/all-3m-products/ \{\}/3M-Bair-Hugger-TemperatureMonitoring-Patient-Sensors-Model-36000/?N=5002385+3291653000\&rt=rud (accessed on 9 October 2018).

29. MacRae, B.A.; Annaheim, S.; Spengler, C.M.; Rossi, R.M. Skin Temperature Measurement Using Contact Thermometry: A Systematic Review of Setup Variables and Their Effects on Measured Values. Front. Physiol. 2018, 9, 1-24. [CrossRef]

30. Ramanauskiene, I.; Skurvydas, A.; Sipaviciene, S.; Senikiene, Z.; Linonis, V.; Krutulyte, G.; Vizbaraite, D. Influence of heating and cooling on muscle fatigue and recovery. Medicina 2008, 44, 687-693. [CrossRef] [PubMed]

31. Sipavičienè, S.; Dumčienè, A. Non-invasive muscle temperature control during cooling. Electron. Electr. Eng. 2013, 19, 42-45.

32. Costello, J.T.; Culligan, K.; Selfe, J.; Donnelly, A.E. Muscle, Skin and Core Temperature after $-110{ }^{\circ} \mathrm{C}$ Cold Air and $8{ }^{\circ} \mathrm{C}$ Water Treatment. PLoS ONE 2012, 7, e48190. [CrossRef]

33. Jutte, L.S.; Merrick, M.A.; Ingersoll, C.D.; Edwards, J.E. The relationship between intramuscular temperature, skin temperature, and adipose thickness during cryotherapy and rewarming. Arch. Phys. Med. Rehabil. 2001, 82, 845-850. [CrossRef] [PubMed]

34. Akgun, K.; Korpinar, M.A.; Kalkan, M.T.; Akarirmak, U.; Tuzun, S.; Tuzun, F. Temperature changes in superficial and deep tissue layers with respect to time of cold pack application in dogs. Yonsei Med. J. 2004, 45, 711-718. [CrossRef] [PubMed]

35. Merrick, M.A.; Knight, K.L.; Ingersoll, C.D.; Potteiger, J.A. The Effects of Ice and Compression Wraps on Intramuscular Temperatures at Various Depths. J. Athletic Train. 1993, 28, 236-245.

36. Merrick, M.A.; Jutte, L.S.; Smith, M.E. Cold Modalities with Different Thermodynamic Properties Produce Different Surface and Intramuscular Temperatures. J. Athletic Train. 2003, 38, 28-33.

37. Dykstra, J.H.; Hill, H.M.; Miller, M.G.; Cheatham, C.C.; Michael, T.J.; Baker, R.J. Comparisons of Cubed Ice, Crushed Ice, and Wetted Ice on Intramuscular and Surface Temperature Changes. J. Athletic Train. 2009, 44, 136-141. [CrossRef] [PubMed]

38. Liu, D.; Ebbini, E.S. Real-Time 2-D Temperature Imaging Using Ultrasound. IEEE Trans. Biomed. Eng. 2010, 57, 12-16. [PubMed]

39. Stauffer, P.R.; Snow, B.W.; Rodrigues, D.B.; Salahi, S.; Oliveira, T.G.; Reudink, D.; Maccarini, P.F. Non-Invasive Measurement of Brain Temperature with Microwave Radiometry: Demonstration in a Head Phantom and Clinical Case. Neuroradiol. J. 2014, 27, 3-12. [CrossRef]

40. Laxminarayan, S.; Rakesh, V.; Oyama, T.; Kazman, J.B.; Yanovich, R.; Ketko, I.; Epstein, Y.; Morrison, S.; Reifman, J. Individualized estimation of human core body temperature using noninvasive measurements. J. Appl. Physiol. 2018, 124, 1387-1402. [CrossRef]

41. Buller, M.J.; Tharion, W.J.; Cheuvront, S.N.; Montain, S.J.; Kenefick, R.W.; Castellani, J.; Latzka, W.A.; Roberts, W.S.; Richter, M.; Jenkins, O.C.; et al. Estimation of human core temperature from sequential heart rate observations. Physiol. Meas. 2013, 34, 781-798. [CrossRef]

42. Potter, A.W.; Blanchard, L.; Friedl, K.E.; Cadarette, B.S.; Hoyt, R.W. Mathematical prediction of core body temperature from environment, activity, and clothing: The heat strain decision aid (HSDA). J. Therm. Biol. 2017, 64, 78-85. [CrossRef] 
43. Imani, F.; Rouzbahani, H.R.K.; Goudarzi, M.; Tarrahi, M.J.; Soltani, A.E. Skin Temperature Over the Carotid Artery, an Accurate Non-invasive Estimation of Near Core Temperature. Anesthesiol. Pain Med. 2016, 6, E31046. [CrossRef] [PubMed]

44. Augustine, G.; Augustine, S. Accurate Non-Invasive Temperature Monitoring Device. In Proceedings of the 2017 Design of Medical Devices Conference DMD2017, Minneapolis, MN, USA, 10-13 April 2017.

45. Chung, S.H.; Mehta, M.; Tromberg, B.J.; Yodh, A.G. Non-invasive measurement of deep tissue temperature changes caused by apoptosis during breast cancer neoadjuvant chemotherapy: A case study. J. Innov. Opt. Health Sci. 2011, 4, 361-372. [CrossRef] [PubMed]

46. Pouch, A.M.; Cary, T.W.; Schultz, S.M.; Sehgal, C.M. In Vivo Noninvasive Temperature Measurement by B-Mode Ultrasound Imaging. J. Ultrasound. Med. 2010, 29, 1595-1606. [CrossRef] [PubMed]

47. Liu, S.; Feng, X.; Ruochong, Z.; Zheng, Y. Portable photoacoustic system for noninvasive blood temperature measurement. In Proceedings of the 2018 IEEE International Symposium on Circuits and Systems (ISCAS), Florence, Italy, 27-30 May 2018; pp. 1-4. [CrossRef]

48. Dumciene, A.; Sipaviciene, S. Deeper-Layer Body Tissue Temperature Control Using Multi-Sensory Transducer. Elektronika ir Elektrotechnika 2015, 21, 24-27. [CrossRef]

49. Pennes, H.H. Analysis of Tissue and Arterial Blood Temperature in the Resting Human Forearm. J. Appl. Physiol. 1948, 1, 93-102. [CrossRef]

50. Lakhssassi, A.; Kengne, E.; Semmaoui, H. Modifed pennes' equation modelling bio-heat transfer in living tissues: Analytical and numerical analysis. Nat. Sci. 2010, 2, 1375-1385. [CrossRef]

51. Katić, K.; Li, R.; Zeiler, W. Thermophysiological models and their applications: A review. Build. Environ. 2016, 106, 286-300. [CrossRef]

52. Coccarelli, A.; Boileau, E.; Parthimos, D.; Nithiarasu, P. An advanced computational bioheat transfer model for a human body with an embedded systemic circulation. Biomech. Model Mechanobiol. 2016, 15, 1173-1190. [CrossRef]

53. McIntosh, R.L.; Anderson, V. A comprehensive tissue properties database provided for the thermal assessment of a human at rest. Biophys. Rev. Lett. 2001, 5, 129-151. [CrossRef]

54. Eston, R.; Peters, D. Effect of cold water immersion on the symptoms of exercise-induced muscle damage. J. Sports Sci. 1999, 17, 231-238. [CrossRef]

55. Mars, M.; Hadebe, B.; Tufts, M. The effect of icepack cooling on skin and muscle temperature at rest and after exercise. S. Afr. J. Sports Med. 2006, 18, 60-66. [CrossRef]

56. Psikuta, A.; Niedermann, R.; Rossi, R.M. Effect of ambient temperature and attachment method on surface temperature measurements. Int. J. Biometeorol. 2014, 58, 877-885. [CrossRef] [PubMed]

57. MacRae, B.A.; Annaheim, S.; Stämpfli, R.; Spengler, C.M.; Rossi, R.M. Validity of contact skin temperature sensors under different environmental conditions with and without fabric coverage: Characterisation and correction. Int. J. Biometeorol. 2018, 62, 1861-1872. [CrossRef] [PubMed]

58. Brazaitis, M.; Eimantas, N.; Daniuseviciute, L.; Mickeviciene, D.; Steponaviciute, R.; Skurvydas, A. Two Strategies for Response to $14{ }^{\circ} \mathrm{C}$ Cold-Water Immersion: Is there a Difference in the Response of Motor, Cognitive, Immune and Stress Markers? PLoS ONE 2014, 9, e109020. [CrossRef] [PubMed]

(C) 2018 by the authors. Licensee MDPI, Basel, Switzerland. This article is an open access article distributed under the terms and conditions of the Creative Commons Attribution (CC BY) license (http:// creativecommons.org/licenses/by/4.0/). 